\title{
CRISIS OR OPPORTUNITY: LOOKING AT THE PAST FOR THE RESILIENCE OF SETTLEMENTS
}

\author{
GULIZ OZORHON \& ILKER FATIF OZORHON \\ Faculty of Architecture and Design, Özyeğin University, Turkey
}

\begin{abstract}
This study focuses on learning from the examples of traditional architecture for planning/designing resilient living environments. It is important for the living environments of the future to take advantage of the ancient knowledge of traditional settlements, which are handed down from generation to generation, centring on "human" and "environment" and knitted with the dynamics of life. Within the scope of the study, 7 traditional settlement examples selected from Anatolia were examined under the titles of settlement, building and technology. The characteristics of these settlements are revealed with their ecological, economic, social and spatial dimensions in relation to their resilience. As a result of the research, all settlement examples were evaluated in an integrated manner, and some determinations were made for future resilient settlements.
\end{abstract}

Keywords: traditional settlement, resilience, learning from past.

\section{INTRODUCTION}

Today, the whole world is trying to adapt to pandemic conditions while trying to develop theories and produce projects on how the life and its dynamics will be shaped after the pandemic. What should the planning principles of post-pandemic living environments be? How should public spaces or housing units transform? Pandemic also made us question whether our living environments are resistant to the crises we may face or not.

The pandemic has shown us how weak we are or can be in the face of unforeseen situations. We came across the reality of how fragile our lives and the spaces we live in can actually be. Moreover, the pandemic was only one of the possible crisis scenarios. With this confrontation, we once again remembered how vulnerable our living spaces are against environmental problems, natural disasters, floods, earthquakes, and climate crisis.

At this point, the eyes of the researchers turned to traditional settlement examples once again after many times, and the main question of the research in this study emerged in this way: Can traditional architectural examples be used for planning/designing resilient living environments?

What is the resilience? According to Ward [1]; "A resilient system is adaptable and diverse. It has some redundancy built in. A resilient perspective acknowledges that change is constant and prediction difficult in a world that is complex and dynamic ... Resilience thinking is a new lens for looking at the natural world we are embedded in and the manmade world we have imposed upon it." Resilience is the capacity of a system to absorb disturbance and reorganize while undergoing change, so as to still remain essentially the same function, structure, identity, and feedbacks [2] Resilience is mainly studied in the context of urban planning in the literature. According to Yaman Galantini [3], defining urban resilience with its ecological, social, socio-ecological, spatial, economic and institutional/governance dimensions is important in terms of constructing the relationship between resilience and urban planning.

On the other hand, traditional principles have evolved over a long period of time all countries of the world. People have developed building techniques excellently adapted to the building materials available and local conditions such as the climate [4]. Recent research has 
emphasised the potential contribution of traditional ecological knowledge to cope with challenges from global environmental change [5]. Since traditional settlements are created based on environmental data, they are easier to adapt to environmental changes.

Anatolian architecture offers an important and rich resource in this respect. Anatolia has been home to many civilizations over the course of history and all of them developed by adding their expertise and knowledge to the total accumulation pool of the landscape they inherited. Every civilization has developed its own building principles by drawing on accumulated knowledge and taking them one step further. Learning from the past and from past expertise and the transfer of knowledge have been key factors in the building traditions of Anatolian civilizations [6]. This study asserts that the argument for learning from the past is still valid. As noted by McIntosh et al. [7] "by ignoring the great laboratory of millennia of responses to environmental change, we condemn ourselves to reinventing a very complex wheel in the face of one of humanity's greatest challenges".

\subsection{Methodology}

This study focuses on learning from traditional settlements for the resilience of existing and new living environments. In this context, the method of the research (Fig. 1) is based on the examination of selected traditional settlement examples with a holistic perspective and with different layers under the headings of settlement (pattern), building (unit) and technology (component). With this examination, the characteristic features of these living environments, which could protect itself against many years and various difficulties, shaped by environmental data, socio-cultural dynamics, habits and the identity of the place, have been tried to be understood. In the study, instead of revealing the settlements one by one, it was preferred to examine them as a whole, so that it was aimed to reveal the strategies repeated in all of them.

In the study, the relationship between the ancient knowledge of traditional settlements and resilience (adapted from Yaman Galanti's [3] approach) is systematically revealed in its ecological, economic, social and spatial contexts.

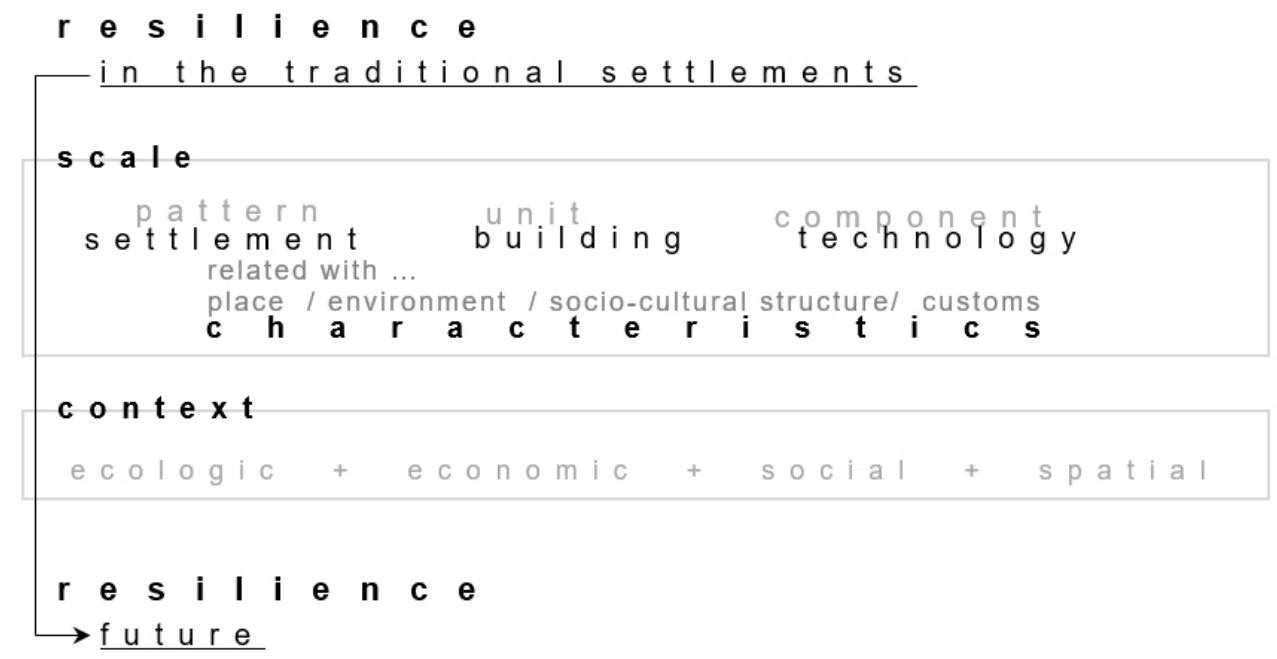

Figure 1: The framework of the study. 


\section{CASE STUDY: INVESTIGATION OF TRADITIONAL SETTLEMENTS IN THE CONTEXT OF RESILIENCE}

In this study, which focuses on the issue of resilience, the knowledge of traditional settlement examples selected from Anatolia is referred. Within the scope of the paper, 7 traditional settlement examples (Antakya, Mardin, Taraklı, Göynük, Cumalıkızık, Uçmakdere, Sille) from Anatolia with varying climatic characteristics were examined (Fig. 2) and these settlements were revealed with their characteristic features. While doing this, an integrated approach was preferred instead of examining the settlements separately, and the settlements were examined under the headings of settlement, building, technology.

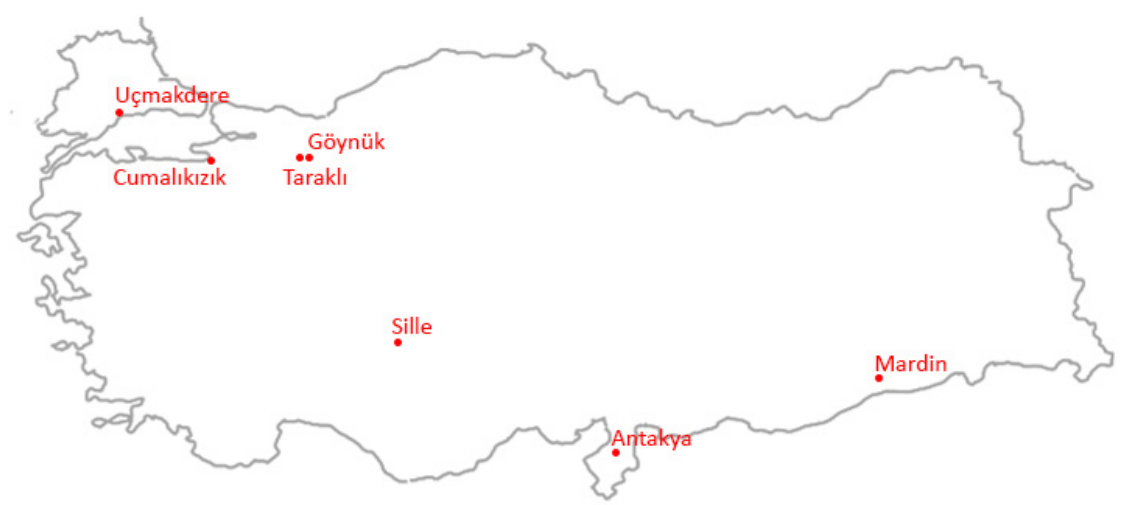

Figure 2: The map that shows the locations of the traditional settlements.

\subsection{Settlements}

Traditional Anatolian settlements have centred nature. For example, an attitude compatible with the topography was displayed in these settlements. Generally, the settlements were established on a sloping area, and the flat land was left to agriculture/production. In the example of Sille, in order to adapt the settlement to the land conditions, vineyards and gardens were built on the flat lands in the valley, and residential settlements on the sloping lands. Settlements in Göynük (Fig. 3), one of the examples that have survived to the present day with little change, and in Tarakl1 (Fig. 4), a typical Ottoman settlement have been shaped parallel to the sloping structure of the land [8]. The narrow streets, which show an organic formation, are sometimes quite inclined due to the topography. In Cumalıkızı, the squares, streets and houses of the village nestling at the foot of the mountain are in harmony with the natural topography [9].

On the other hand, one of the most important features of these settlements is that they are formed according to the climate. For example, the strong climatic conditions of Mardin (Fig. 5 ), played key roles in the way the architecture was developed. The hot and dry climate ranks at the top of these climatic conditions. Therefore, the pattern of the city developed to harmonize with this hot climate [9]. The narrow streets, where only one car can pass, are shaped according to the climate and prevailing winds. For example, in Antakya (Fig. 6), the streets are formed in such a way that the wind blowing from the Asi River refreshes the city in the summer months while they receive sun light in the winter [10]. In hot climatic regions (in the examples of Mardin and Antakya), narrow streets create sheltered and shady transition areas for the hot and overwhelming effect of summer. 


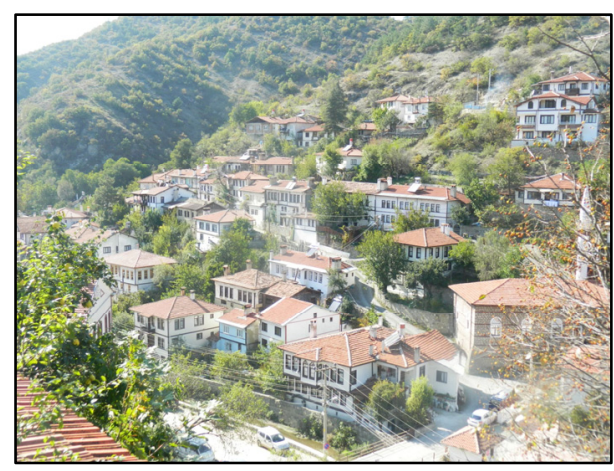

Figure 3: Göynük. (Source: Authors.)

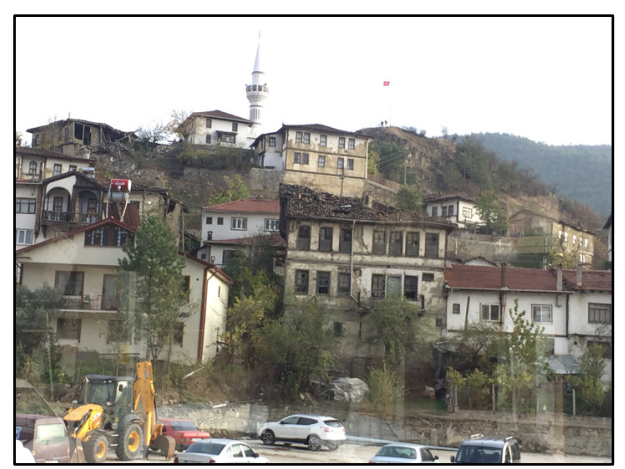

Figure 4: Tarakl1. (Source: Authors.)

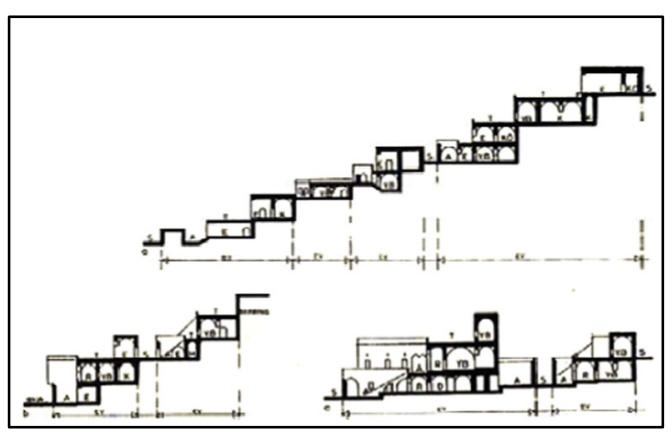

Figure 5: Mardin. (Source: F. Alioğlu.)

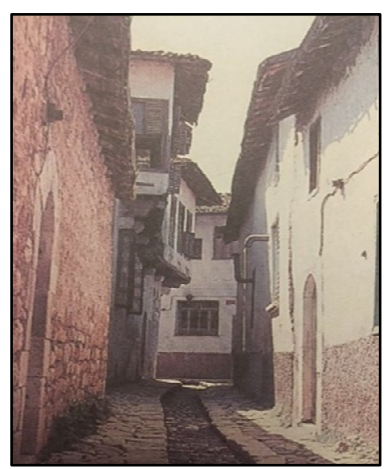

Figure 6: Antakya. (Source: C. Bektaş.)

Streets are also narrow in Uçmakdere (Fig. 7) which was established on a sloping land towards the mountain foot. Some houses were built in adjacent order, while some houses were built individually in a garden. The middle of the cobbled streets is inclined like a canal, and both sides are left high. Thus, in the village, which was established on a sloping land, when it rained, the water flowing from the midway was transferred directly to the creek. There is no accumulation of water in any part of the village [11]. It is possible to see a similar approach in many traditional settlement examples. For example, streets in Sille are extremely narrow. The middle of the stone-paved streets are arranged in the form of gutters to channel the water coming from above [12]. A similar attitude can be seen when looking at the cross sections of the streets in Antakya. The gutters in the middle of the streets allow the rain water flowing down the mountain skirts to reach the Asi River in a controlled manner [10].

\subsection{Buildings}

In traditional settlements, houses show a similar approach in terms of scale, system and material. In the settlements, the houses are mostly located adjacent to the street boundary or in a separate order in the gardens. Due to the topographical structure in Sille; The privacy of 


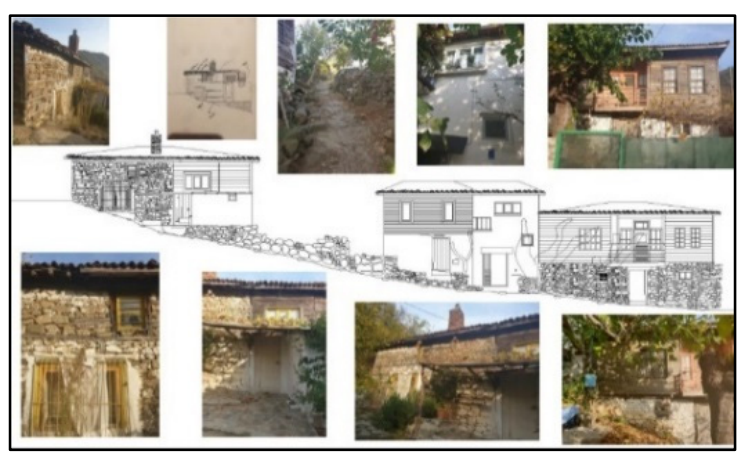

Figure 7: Uçmakdere. (Source: Visuals and drawings - T. Çınar.)

the houses is also provided by the gradual settlement of traditional houses, streets and neighbourhoods. An architecture in harmony with nature was created while ensuring that the buildings benefit from the sun and the landscape equally [13]. The fact that Göynük houses do not block each other's outlook, sun and even air due to respect for the environment and neighbours can be associated with social life discipline. In Göynük, the organic street (Fig. 8 ) texture shaped by the topography and the parcel layouts of the houses have been created, and the fact that the streets are perpendicular or parallel to the slope has been determinant in the settlement of the houses within the parcel [8]. Traditional houses, which make up the urban texture of Göynük, can be accessed from different streets and levels thanks to their appropriate use of topography.

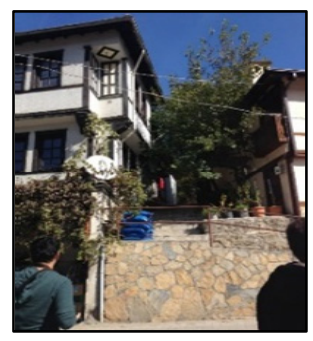

Figure 8: Göynük. (Source: Authors.)

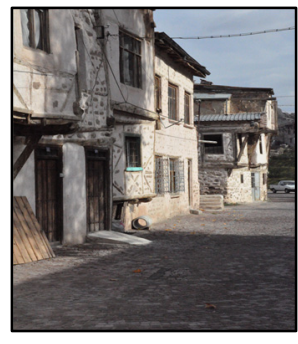

Figure 9: Sille. (Source: Authors.)

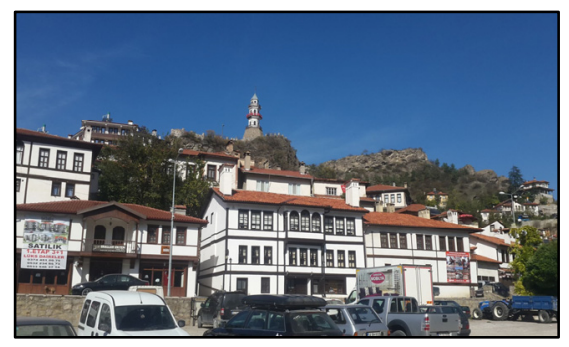

Figure 10: Göynük. (Source: Authors.)

These houses have developed in harmony with the life culture, habits, social structure and human scale. Natural events that have been going on for centuries in traditional life are an important part of the life culture. The process of production that progresses with the soil, sun and rain has shaped the daily life and the places where this life takes place (Fig. 9). The production that started in the field continues at home as well. For this reason, the formation of open/semi-open spaces that will allow this, gains importance in shaping the houses.

These places are shaped according to the climate and take local names (hayat, taşlik, ...). For example, in Tarakl1, courtyards are behind the house and these courtyards are surrounded by mud brick, stone or wooden walls. In the courtyards there are areas not only for daily life 
activities, but also for warehouses, haystacks, ovens and poultry [14]. In Göynük houses, stone-paved courtyards, which are surrounded by walls and also known as "taşlik", are open spaces that are used extensively. The bakery, where meals are also cooked on feast days take place in the courtyards, in parallel with the economic situation of the owner of the house. In some cases it is seen that the gusulhouses (the place where Muslims have a bath) on the living floor are also located in the courtyards. In some courtyard examples there is a pool for cooling, and in a small number of examples there is a toilet placed in a corner of the courtyard [8]. In Mardin, courtyards have fountains or small pools that support the microclimate. One of the features of the traditional houses is that they have iwans situated between the rooms. An "Iwan" (eywan) is a roofed space that is usually three-walled, affording open access to the courtyard. These spaces are very functional for the residents, especially in summer [9]. When the plans of Antakya houses are examined, the courtyard is always in the center. The rooms are located on one, two or three sides of the courtyard. It is important that the courtyards are functional, restful and simple. Landscape elements that create shade and coolness are also important [10]. Another important element of traditional Anatolian architecture is the "sofa". Just as the houses open to a street, every room in the house opens to sofa. The Sofa is an access to the rooms, as well as a space where all households gather and ceremonies are held [15]. In the spatial organization of Göynük houses, residential types with internal and external halls (sofa) which are shaped according to whether the hall is open or closed to the outside, stand out more. In the living floors of the houses that have survived to the present day in Göynük, plan schemes with internal hall ("cleavage" plan) and external hall has been used [8].

One of the most important principles of traditional houses is flexibility. "The houses are capable of growing with the family; one unit at a time. Or that can be divided up later on ..." [16]. Therefore, one of the most important elements of these houses is the room. Each room in the house is equipped to accommodate a family (husband and wife). Here you can sit, sleep, cook, eat and even have a bath. One of the rooms in the houses is different from the others. In this place, which is called as the head room, guests are welcome. This most equipped room is the closest one to the stairs and it has the best view.

\subsection{Technology}

The basic parameters that shape the façade in traditional houses are entrance, projections, doors and windows, the number of floors and the roof. The diversity seen in the plans of the houses is also reflected in the exterior façades. The arrangement of the windows on the street façades, which enable them to orient themselves to the view from a wide angle, is shaped by the size and spatial function of the space they are in [8].

Natural and local materials were used in traditional settlements. As Bektaş [16] pointed out "the materials used can be obtained easily from nature, the building method are not pushed to their limits...one always seeks solutions that achieves more with less, are smarter are simpler...". For example, in Göynük houses, the ground floor is made of stone masonry on the stone foundation walls, and the upper floor is made of timber carcass, brick or mud brick filling material (Fig. 10) The use of wood in buildings is common due to the availability of wood in the region, its abundance and low cost. Similarly in Cumalıkızık, The structures of most Cumalıkızık are formed with timber as its basic timber construction material. In Cumalıkızık houses, the construction system is a hybrid system that includes a ground floor setting and a carcass system for upper floors. Stone, adobe bricks and regular bricks are among the construction materials used [9]. 
When the traditional structures in Taraklı (Fig. 11) are examined in terms of construction system and material; it is seen that the buildings were built in adobe or brick filled wooden carcass system. Since the region is covered with forests, the easiest building material to obtain is wood. The timber pillars resting on the stone foundation walls create a rigid system with the floor covering and the upper floor frame. The biggest reason why Tarakl, which is in the first degree earthquake zone, survived the earthquakes with insignificant damages is shown as that the majority of the buildings in the city have a traditional timber carcass system [15].

In Mardin, limestone found in deposits near the city is the basic construction material. While limestone is used for the primary supporting element of the structure, it is also used to ornament the buildings. The types of limestone used for these diverse purposes are different from each other. The stones used for the building material are clear yellow and hard, while the stones used as ornamentation are still soft when they are removed from the stone quarry [17]. in the micro-climate of the Mardin region, with hot and dry summers and significant temperature changes between day and night, the customarily thick walls perform both as heat reservoirs and insulators. During the hot day, the heat flow from the exterior due to the solar radiation to the inside is retarded and stored. Part of the heat is gradually released during the cooler hours, especially at night. In the cold winter months these thick walls reduce heating requirements because the heat stored in the walls is radiated during the night [9].

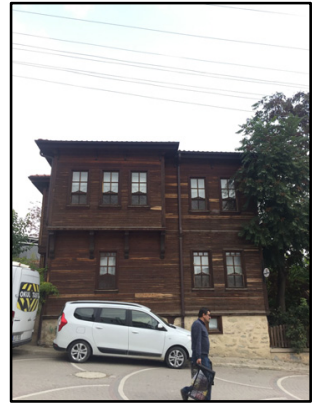

Figure 11: Tarakl1. (Source: Authors.)

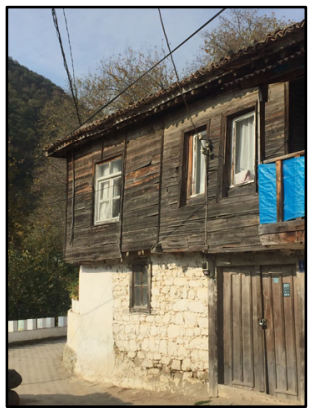

Figure 12: Uçmakdere. (Source: Authors.)

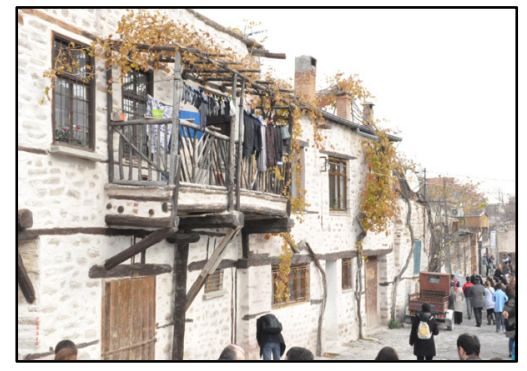

Figure 13: Sille. (Source: Authors.)

The dominant building material in the buildings in Sille (Fig. 13) is stone. Sille stone, which is easy to obtain and use, is a type of volcanite and andesite characteristics extracted from the quarries $2-3 \mathrm{~km}$ south of Sille [18]. It is used as both wall and flooring material. The structures in Sille were built by the craftsmen of Sille. As a result of being as strong and durable as possible, they have survived until today with various repairs [19]. Antakya houses are generally two-storey, made of stone and mud brick. The thick main walls on the ground floor are generally covered with hammer-dressed stones, and the upper floors are a light construction, which is mostly made with a bagdadi technique [10].

\section{HOLISTIC EVALUATION}

What Velinga says about vernacular architecture is also a pertinent remark about learning from the past: "If the aim is truly to learn from vernacular architecture, what is needed is a 
Table 1: The features of the traditional settlements in the context of the resilience.

\begin{tabular}{|c|c|c|c|c|}
\hline & Ecologic & Economic & Social & Spatial \\
\hline \multirow{9}{*}{ 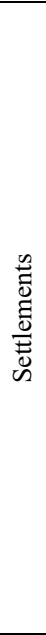 } & \multicolumn{2}{|c|}{ Settlement compatible with topography } & & $\begin{array}{l}\text { Settlement compatible with } \\
\text { topography }\end{array}$ \\
\hline & \multicolumn{2}{|c|}{ Settlement compatible with climate } & & Settlement compatible with climate \\
\hline & \multicolumn{2}{|c|}{ Settlement compatible with sun } & & Settlement compatible with sun \\
\hline & Protection of green areas & & & \\
\hline & & \multicolumn{3}{|c|}{ Integrated-compact settlement } \\
\hline & \multicolumn{2}{|c|}{$\begin{array}{l}\text { Settlements on the slopes, leaving the } \\
\text { flat areas for agricultural land }\end{array}$} & & \\
\hline & & & $\begin{array}{l}\text { Taking into account } \\
\text { each other's } \\
\text { possibilities in the } \\
\text { formation of the } \\
\text { building }\end{array}$ & \\
\hline & & & $\begin{array}{l}\text { Individuals with } \\
\text { different beliefs and } \\
\text { habits are together }\end{array}$ & \\
\hline & $\begin{array}{l}\text { Streets compatible with } \\
\text { topography and flow of } \\
\text { water }\end{array}$ & & & $\begin{array}{l}\text { Streets compatible with topography } \\
\text { and flow of water }\end{array}$ \\
\hline \multirow{9}{*}{$\stackrel{\substack{0 \\
:}}{:}$} & \multicolumn{4}{|c|}{ Low rise buildings compatible with human scale } \\
\hline & \multicolumn{2}{|c|}{$\begin{array}{l}\text { Façade openings (windows) compatible } \\
\text { with climate conditions }\end{array}$} & & \\
\hline & \multicolumn{4}{|c|}{ Building size to fit family needs (whatever is needed, neither more nor less) } \\
\hline & \multicolumn{4}{|c|}{ The shaping of the house to be able to be divided and articulated } \\
\hline & & & \multicolumn{2}{|c|}{$\begin{array}{l}\text { Possibility of using both private (room) and collective } \\
\text { (sofa) space }\end{array}$} \\
\hline & & & \multicolumn{2}{|c|}{ Housing unit suitable for family structure and needs } \\
\hline & & & \multicolumn{2}{|c|}{$\begin{array}{l}\text { Open and semi-open spaces are shaped according to the } \\
\text { requirements of social life and place (hayat, iwan, } \\
\text { courtyard) }\end{array}$} \\
\hline & & & & $\begin{array}{l}\text { The rooms and the equipment in } \\
\text { the rooms are designed to allow } \\
\text { this space to respond to many } \\
\text { functions (sitting, eating, washing, } \\
\text { sleeping, storage). }\end{array}$ \\
\hline & & & & $\begin{array}{l}\text { Planning of furniture integrated } \\
\text { with the walls }\end{array}$ \\
\hline \multirow{5}{*}{$\begin{array}{l}\text { को } \\
\frac{0}{0} \\
\stackrel{0}{0} \\
0 \\
.\end{array}$} & $\begin{array}{l}\text { Structural system and } \\
\text { material selection } \\
\text { compatible with } \\
\text { geological features }\end{array}$ & & & $\begin{array}{l}\text { Structural system and material } \\
\text { selection compatible with } \\
\text { geological features }\end{array}$ \\
\hline & $\begin{array}{l}\text { Usage of natural } \\
\text { materials }\end{array}$ & & & \\
\hline & & \multicolumn{2}{|c|}{$\begin{array}{l}\text { Usage of materials chosen from } \\
\text { nearby areas }\end{array}$} & \\
\hline & \multicolumn{2}{|c|}{$\begin{array}{l}\text { Façade openings (windows) compatible } \\
\text { with climate conditions }\end{array}$} & & \\
\hline & & & \multicolumn{2}{|c|}{ Façades compatible with living habits and traditions } \\
\hline
\end{tabular}

holistic, integrated and critical approach that complements the study of the environmental qualities and performance of vernacular architecture with an examination of its social, political and economic aspects" [20].

Similarly, here, the resilience of the settlements is examined with their ecological, economic, social and spatial contexts based on the approaches of [21]. Ecological resilience 
refers to develop a model that describes changes in structure and function; social resilience refers to the ability of society to cope with threats as a result of social, political and environmental change; spatial resilience refers to the provision of infrastructure requirements for socio-economic resilience, while economic resilience refers to the capacity of an economy to recover from or adapt to the negative effects of external shocks and to take advantage of positive shocks [3], [22]-[26].

In this part of the study, the common characteristics of the settlements are represented in ecologic, economic, social and spatial contexts under the headings of settlement, buildings and technology (Table 1).

Bektaş [16] listed the characteristics of the traditional Turkish house as being compatibility with nature, environmental conditions and lifestyle, reality and rationalism, the inside-out solution, harmony between the interior and exterior, frugality, dimensions to be based on human body, ease of use, choosing the materials and construction techniques from nearby areas and flexibility. Traditional settlements compatible with topography and climate are instructive in terms of energy efficiency and conscious resource use. The establishment of the settlements in parallel with the topography enabled the construction of buildings with minimum intervention to the soil/land and thus to the nature [15]. The fact that the buildings are oriented to the south (to the sun) provided the opportunity to make maximum use of daylight and solar energy, thus it was possible to meet some of the energy use for lighting and heating naturally. Especially in the houses, it is seen that the living spaces are located to the south and the service volumes to the north. The houses were built in the required size and compactly, which prevented material and energy consumption. The buildings were created with natural/local materials (such as wood, stone) that can be easily obtained from the immediate surroundings (structure, shell and spaces), thus both healthy spaces were created and material procurement was easily provided [15]. The use of natural/local materials in the immediate surroundings of the buildings has had many advantages. In this way, healthy and qualified spaces have been designed and logistical convenience has been provided while, on the other hand, the characteristic identity of this place has been formed spontaneously.

\section{CONCLUSION}

According to the results of the study conducted by Gomez Traditional ecological knowledge and shared systems of beliefs can facilitate collective responses to crises and contribute to the maintenance of long-term resilience of social-ecological systems [5]. Indeed, traditional settlements have been established by reading/understanding nature, with the strong knowledge that has been articulated over the centuries. In addition to this knowledge, today there is a huge accumulation of science and technology that can serve human beings. Despite all of this, settlements are damaged, buildings collapse and people die due to disasters such as earthquakes or floods in many parts of the world today. Moreover, most of these disasters are not caused by earthquakes or floods - they are cities and buildings created by ignoring the knowledge of the past and the present. We should take the traditional settlements that have survived for hundreds of years and that are aware of the structural features of the soil/place they are connected to, as an example. The streets shaped according to the flow of water in these environments also allow the flow and continuity of nature. While planning the development routes and transportation axes of cities, we should include nature, and be sensitive and responsible for the ecological impact of the spread of our living spaces.

We should rethink the building envelope construction of traditional architecture, which is oriented according to the climate/sun, transformed according to the seasonal characteristics of the location, and shaped with natural/recyclable material. Undoubtedly, there is a lot to learn from this attitude in terms of energy use. We should rethink the culture of space that 
develops in parallel with life. While the pandemic pushed the whole world to live within their own homes, we mostly felt the lack of open living spaces. Our huge buildings, shopping centers, restaurants, and office towers became unusable when the air conditioners did not work. We remembered that the places we live in also need fresh air and sunlight. However, in traditional houses, there were courtyards, hayat, trees in these places, surrounding these spaces were healthy breathing shells made of stone, adobe or wood. We should expand the scope of sustainable architecture research and applications. We should raise awareness for all actors of building production that the features of the place should be included in every phase of the architectural design process.

As Bektaş [16] stated, now "we have to change our living culture." While planning our living environments at different scales (from home to street to city) from the smallest to the largest, we should turn to the concept of space that puts nature and people at the centre. Instead of struggling with nature, we should develop strategies that are in harmony with nature and according to the current dynamics of life. Problems such as climate crisis, global warming and famine are always on the agenda. However, we must be aware that we cannot produce real solutions to these problems without questioning our living habits. Undoubtedly, life continues to change at full speed. Of course, we cannot reproduce traditional settlement examples as they are today, but we must not forget that there is an important accumulation of knowledge in the strong relationship they establish with their own contexts. While we are constructing our living environments, we have to be consistent in our contextual approach, including the necessities of time and the dynamics of life, and we should think in a multifaceted way. With the guidance of science and this source of information provided by traditional settlements, we have to say new things and develop new strategies for our living spaces.

\section{REFERENCES}

[1] Ward, C., Diesel-Driven Bee Slums and Impotent Turkeys: The Case for Resilience. TomDispatch.com. Accessed on: 20 Mar. 2021.

[2] Walker, B., Holling, C.S., Carpenter, S.R. \& Kinzig, A., Resilience, adaptability and transformability in social-ecological systems. Ecology and Society, 9(2), p. 5, 2004.

[3] Yaman Galantini, Z.D., Belirsizliklere karşı kurumsal dayanıklılık ve beş bileşenli kent planlama süreci (Institutional resilience against uncertainties and five-elements urban planning process). Planlama, Kavramlar ve Araylşlar, 43rd Annual World Urbanism Day Colloquium, Ankara, 7-9 Nov. 2021.

[4] Oliver, P., Encyclopedia of Vernacular Architecture of the World, Cambridge University Press: Cambridge, 1997.

[5] Gómez-Baggethun, E., Reyes-García, V., Olsson, P. \& Montes, C., Traditional ecological knowledge and community resilience to environmental extremes: A case study in Doñana, SW Spain. Global Environmental Change, 22(3), pp. 640-650, 2012.

[6] Ozorhon, G. \& Ozorhon, I.F., Learning from vernacular architecture in architectural education. Megaron, 15(4), pp. 553-564, 2020.

[7] McIntosh, R.J., Tainter, J.A., McIntosh, S.K., Climate, history and human action. The Way the Wind Blows: Climate, History, and Human Action, eds R.J. McIntosh, J.A. Tainter \& S.K. McIntosh, Columbia University Press: New York, pp. 1-42, 2000.

[8] Dikmen, Ç.B. \& Toruk, F., Spatial structure and proposals of protection of traditional houses Göynük. Afyon Kocatepe University Journal of Social Sciences, 17(1), pp. 99$128,2015$.

[9] Ozorhon, G. \& Ozorhon, I.F., Learning from Mardin and Cumalıkızık: Turkish vernacular architecture in the context of sustainability. Arts, 3(1), pp. 175-189, 2014. 
[10] Arıman, B., Typological analysis in the ancient texture of the City of Antakya. Unpublished Master's thesis, Istanbul Technical University, Institute of Science and Technology, 2002.

[11] Kurtuluş, I.H., Tekirdă̆ coastal line survey (Mürefte Yukarı Kalamış, Tepeköy, Çınarlı, Hoşköy, Güzelköy, Gaziköy, Uçmakdere, Yeniköy, Kumbağ, Barbaros). Unpublished master thesis, Istanbul University, Institute of Social Sciences, İstanbul, 1992.

[12] Tapur, T., Konya'da Tarihi Bir Yerleşim Merkezi: Sille (A historical settlement in Konya: Sille). Türk Coğrafya Dergisi, 53, pp. 15-30, 2009.

[13] Keleş, R., An assessment of the sustainability of the relationship between traditional craft and interior space: The case of Sille village. Unpublished master thesis, Selçuk University, Institute of Social Sciences, Konya, 2019.

[14] Davulcu, M., Sakarya yöresi kırsal yerleşmelerinde konut mimarisi ve ustalık geleneği üzerine bir inceleme (A study on house architecture and master tradition in the rural settlements of Sakarya province). Kastamonu Eğitim Dergisi, 17(2), pp. 687-706, 2009.

[15] Ozorhon, G. \& Ozorhon, I.F., Rural architecture and sustainability: Learning from the past. Journal of Asian Rural Studies, 5(1), pp. 30-47, 2021.

[16] Bektaş, C., Türk Evi (Turkish House), Yapı Endüstri Merkezi Yayınları, 2012.

[17] Alioğlu, F., Mardin Şehir Dokusu ve Evler, Tarih Vakfı Yayını: İstanbul, 2000.

[18] Aklanoğlu, F., Sustainability of traditional settlements and ecological design: A case study on Sille. Unpublished PhD thesis, Ankara University, Ankara, 2009.

[19] Tazefidan, C., Evaluation of Sille Houses by space-syntax method. Unpublished master thesis, Selçuk University, Fen Bilimleri Enstitüsü, Institute of Science and Technology, Konya, pp. 50-53, 2018.

[20] Vellinga, M., The noble vernacular. The Journal of Architecture, 18(4), pp. 570-590, 2013.

[21] Yaman-Galantini, Z.D., Urban resilience as a policy paradigm for sustainable urban planning and urban development: The case of Istanbul. Unpublished $\mathrm{PhD}$ thesis, Istanbul Technical University, 2018.

[22] Holling, C.S., Understanding the complexity of economic, ecological and social systems. Ecosystems, 4, pp. 390-405, 2001.

[23] Abesamis, N.P, Corrigan, C., Drew, M., Campbell, S. \& Samonte, G., Social resilience: A literature review on building resilience into human marine communities in and around MPA networks. MPA Networks Learning Partnership, Global Conservation Program, USAID, 2006.

[24] Adger, W.N., Social and ecological resilience: Are they related. Progress in Human Geography, 24(3), pp. 347-364, 2000.

[25] Keck, M. \& Sakdapolrak, P., What is social resilience? Lessons learned and ways forward. Erdkunde, 67(1), pp. 5-19, 2013.

[26] Gotham, K.F. \& Campanella, R., Toward a research agenda on transformative resilience: Challenges and opportunities for post-trauma urban ecosystems. Critical Planning Summer, pp. 9-23, 2010. 